\title{
In search of targeted therapies for childhood cancer
}

\section{Crystal L. Mackall*}

Pediatric Oncology Branch, National Cancer Institute, Bethesda, MD, USA

*Correspondence: cm35c@nih.gov

Progress made in the battle to cure childhood cancer is one of the great success stories of modern medicine. Some diseases that were universally fatal 50 years ago, such as pediatric acute lymphoblastic leukemia, can now be cured in approximately $80 \%$ of patients (Margolin et al., 2011). Current standard therapies for children with Wilm's tumor, thyroid cancer, Hodgkin disease, and Burkitt's lymphoma cure more $90 \%$ of patients and overall 10-year. survival rates for children treated for cancer in developed countries is approximately 75\% (Scheurer et al., 2011). Despite these successes, there are substantial limits to our progress. Equivalent gains have not occurred across all histologies, disease stages, epidemiologic subgroups and global populations, and cure is associated with substantial long-term morbidity and increased mortality.

Diseases such as diffuse intrinsic pontine glioma (DIPG) vividly illustrate the limits of progress against childhood cancer. No significant improvements in outcome for patients with DIPG have occurred despite years of clinical and basic research, and more than $90 \%$ of patients with DIPG die within 2 years of diagnosis, despite radiation therapy, which is the only standard treatment available (Hargrave et al., 2006). Survival rates remain $<30 \%$ for patients with metastatic pediatric sarcomas, and these are unchanged from those observed in the 1970s, despite the fact that progressive improvements in survival have occurred in patients with the same histologies, but without clinical evidence for metastases (Raney et al., 2001; DuBois and Grier, 2009; Ladenstein et al., 2010). Modest progress has been made against high-risk neuroblastoma, acute myeloid leukemia, and non-DIPG pediatric brain tumors, but cure rates still approximate $50 \%$ for these diseases. Furthermore, while outcomes for most pediatric cancers have clearly improved over the last 50 years, the rate of progress in the last decade has slowed overall, and new therapies that are likely to substantially improve cure rates in the next $5-10$ years are not readily apparent.
Progress against childhood cancer has also been unbalanced with regard to patient age, ethnicity, and race. For a variety of childhood cancers, infants, adolescents, and young adults have not experienced the same increase in survival rates that have been observed for children (Scheurer et al., 2011). In some diseases, such as rhabdomyosarcoma and acute lymphoblastic leukemia, at least some of the age related differences in survival are largely driven by differences in tumor subtype, such that less treatment responsive tumors occur in infants and older age groups (Pieters, 2009; Perez et al., 2011; Tricoli et al., 2011). However for Ewing's sarcoma, outcomes are consistently lower for adolescents and adults, yet there is no evidence that the biology of the tumor changes with age, raising the prospect that the differences in survival rates may relate to host or treatment factors (Maki, 2008). With regard to ethnicity and race, several multicenter studies have demonstrated that Hispanic and black children with acute lymphoblastic leukemia and acute myeloid leukemia have lower survival outcomes compared to white non-Hispanic and Asian children (Pollock et al., 2000; Bhatia et al., 2002; Children's Oncology Group et al., 2006; Lange et al., 2008; Bhatia, 2011), and lower survival rates are also observed in black children with Hodgkin disease compared to white children (Percy et al., 1999). There is evidence to suggest that inferior outcomes in these populations may reflect a combination of factors, including differences in disease subtype prevalence (Aldrich et al., 2006; Harvey et al., 2010), pharmacogenomic differences that effect tolerance to therapy (Hon et al., 1999), availability of marrow transplant donors (Lange et al., 2008) as well as access to care, and this is an important area for future study.

The greatest imbalance in outcomes relates to the treatment of childhood cancer in the developing world. Worldwide, it is estimated that 160,000 children are diagnosed with cancer each year, and that approximately 90,000 children die of cancer each year. As noted above, approximately
$75 \%$ of children with cancer in developed countries are cured of their disease, whereas cure rates are estimated to be $10-20 \%$ in the world's poorest countries and many children are not even treated for their disease due to inadequate access to care. Thus, the compelling survival rates from developed countries belie the global toll of childhood cancer.

Much of the improved survival accomplished in pediatric oncology has resulted from the administration of dose intensive cytotoxic chemotherapy and radiotherapy, both of which induce substantial long-term late effects. The Children's Cancer Survivor Study, which evaluated late effects in more than 10,000 US children treated for cancer between 1970 and 1986, demonstrated that two-thirds of all childhood cancer survivors suffer from a chronic condition and more than $40 \%$ are estimated to suffer a severe, disabling, or life-threatening condition 30 years after their diagnosis (Oeffinger et al., 2006). Similar results were seen in a large European study (Geenen et al., 2007), which also demonstrated that radiotherapy is a major factor increasing the severity of late effects. In general, patients cured of Hodgkin disease, brain tumors, and bone tumors appear to be at greatest risk for late effects due to cancer therapy (Oeffinger et al., 2006; Geenen et al., 2007).

Thus, while the "cup is half-full" perspective on childhood cancer is often emphasized, plateaus in progress, unbalanced outcomes across diseases and patient groups, and alarming rates of late effects emphasize a pressing need for new targeted therapies, which are less toxic and more effective. Progress in the development of targeted therapies for childhood cancer has lagged behind that in adult oncology. The reasons for this are manifold, including the fact that large financial markets and the lack of other effective therapies for many adult cancers energized the search early for targeted therapies for adult cancers. Despite the dramatic increases in the numbers of targeted therapies approved for adult cancer in the last 15 years, only a small number 
of these agents have demonstrated activity in childhood cancer (Table 1) and these target a miniscule fraction of children diagnosed with cancer annually. For example, bcr-abl inhibitors are effective as single agents and adjuncts in pediatric CML and $t(9 ; 22)$ ALL respectively, but these diseases are quite rare in pediatrics, representing $<5 \%$ of all pediatric leukemia. Thus, in 2011, most children with cancer continue to receive treatment regimens based upon dose intensive cytotoxics, rather than targeted therapies.

A variety of exciting targets have been identified in common pediatric tumors and progress is underway to translate these insights into clinical benefit. Among the most promising are drugs that have activity in adult tumors and also target oncogenes believed to be important for pediatric tumors (see Figure 1, Pathway \#1). For example, drugs targeting anaplastic lymphoma kinase, have shown significant activity in non-small cell lung cancer, and these also appear to be active in $t(2 ; 5)$ anaplastic large cell lymphomas, which comprise approximately $15-20 \%$ of childhood lymphomas (Gambacorti-Passerini et al., 2011). ALK inhibitors may also be active in the rare familial neuroblastoma with mutated ALK (Janoueix-Lerosey et al., 2008; Mosse et al., 2008), and/or in neuroblastomas and other pediatric solid tumors with ALK amplification (Passoni et al.,
2009). Similarly, promising results have been seen with JAK2 inhibitors in myeloproliferative diseases in adults (QuintasCardama et al., 2011). JAK2 was recently identified as a mutated oncogene in highrisk and Down's syndrome associated acute lymphoblastic leukemias (Bercovich et al., 2008; Gaikwad et al., 2009; Mullighan et al., 2009) and thus studies with JAK2 inhibitors in JAK2 mutated pediatric ALL are anxiously awaited. Activating mutations in BRAF are present in approximately $50-60 \%$ of adults with melanoma and treatment with BRAF inhibitors has yielded impressive responses (Poulikakos and Rosen, 2011). Several pediatric tumors including melanoma, juvenile pilocytic astrocytoma, and other low grade gliomas in pediatrics demonstrate BRAF mutations which may be amenable to the agents currently under study (Dougherty et al., 2010; Schindler et al., 2011). Drugs such as these, which are being successfully developed for adult cancers, and which are also active in pediatric cancer represent the "low hanging fruit," and should be studied in children with cancers bearing the targets as rapidly as possible.

A second, and more challenging, model occurs when targeted agents show insufficient promise in adult cancers to merit further commercial development, yet preclinical or early clinical studies suggest potential activity in pediatric cancer
(Figure 1, Pathway \#2). For example, the IGF1 signaling pathway seems to be a significant axis for targeting Ewing's sarcoma, with an overall 10-15\% objective response rate as a single agent in patients with refractory disease (Patel et al., 2009). While it is unclear if this response rate as a single agent is sufficient for FDA approval, multiagent therapies could be effective. However, it remains unclear whether these agents will remain available for study in pediatric oncology as commercial development has been abandoned by many companies, due to insufficient activity in adult cancers. NOTCH is mutated in approximately $50 \%$ of T-cell ALL, but NOTCH inhibitor studies in adult cancer have not demonstrated dramatic efficacy as yet, and pediatric studies are ongoing. Flt3 inhibitors have been studied in Flt3 mutant adult AML and results thus far have not confirmed significant activity (Levis et al., 2011), raising the possibility that pediatric studies may yield negative results as well or that these agents will not be made available for study in children.

In some cases, negative results in adult cancers could prevent unnecessary studies in children with cancer, where patient numbers are small and studies must be highly prioritized. However, it seems likely that there may be situations where the possibility remains that a targeted agent is active against a pediatric cancer but failure to

Table 1 | FDA approved targeted agents with demonstrated activity in pediatric cancers.

\begin{tabular}{|c|c|c|c|}
\hline \multirow[t]{2}{*}{ Target } & \multirow[t]{2}{*}{ FDA approved agent(s) } & \multicolumn{2}{|r|}{ Disease activity } \\
\hline & & Adult cancers & Pediatric cancers \\
\hline c-Kit & Imatinib & $\begin{array}{l}\text { c-Kit mutated gastrointestinal stroma } \\
\text { tumor (GIST)*, systemic mastocytosis }\end{array}$ & Systemic mastocytosis (Hoffmann et al., 2008) \\
\hline CD20 & $\begin{array}{l}\text { Rituximab; ofatumumab; } \\
\text { tositumomab; 131I-tositumomab; } \\
\text { ibritumomab }\end{array}$ & Non-Hodgkin lymphoma & $\begin{array}{l}\text { CD20+ B-cell non-Hodgkin lymphoma including Burkitt } \\
\text { lymphoma, DLBCL, and some ALL (Attias and Weitzman, } \\
\text { 2008; Reiter et al., 2009; Meinhardt et al., 2010) }\end{array}$ \\
\hline PDGFR & Imatinib & $\begin{array}{l}\text { Dermatofibrosarcoma protuberans } \\
\text { (DFSP) }\end{array}$ & $\begin{array}{l}\text { Dermatofibrosarcoma protuberans (DFSP; Price et al., } \\
\text { 2005) }\end{array}$ \\
\hline $\begin{array}{l}\text { Retinoic acid } \\
\text { receptor }\end{array}$ & Tretinoin; alitretinoin; isotretinoin & $\begin{array}{l}\text { AIDS-related Kaposi sarcoma; acute } \\
\text { promyelocytic leukemia }\end{array}$ & Acute promyelocytic leukemia; neuroblastoma \\
\hline CD52 & Alemtuzumab & $\begin{array}{l}\text { Chronic lymphocytic leukemia (CLL); } \\
\text { cutaneous T cell lymphoma (CTCL); T-cell } \\
\text { lymphoma }\end{array}$ & ALL (Angiolillo et al., 2009) \\
\hline
\end{tabular}

*Pediatric GIST does not express mutated c-kit, and imatinib has not shown activity in pediatric GIST (Pappo and Janeway, 2009; Janeway et al., 2011). 

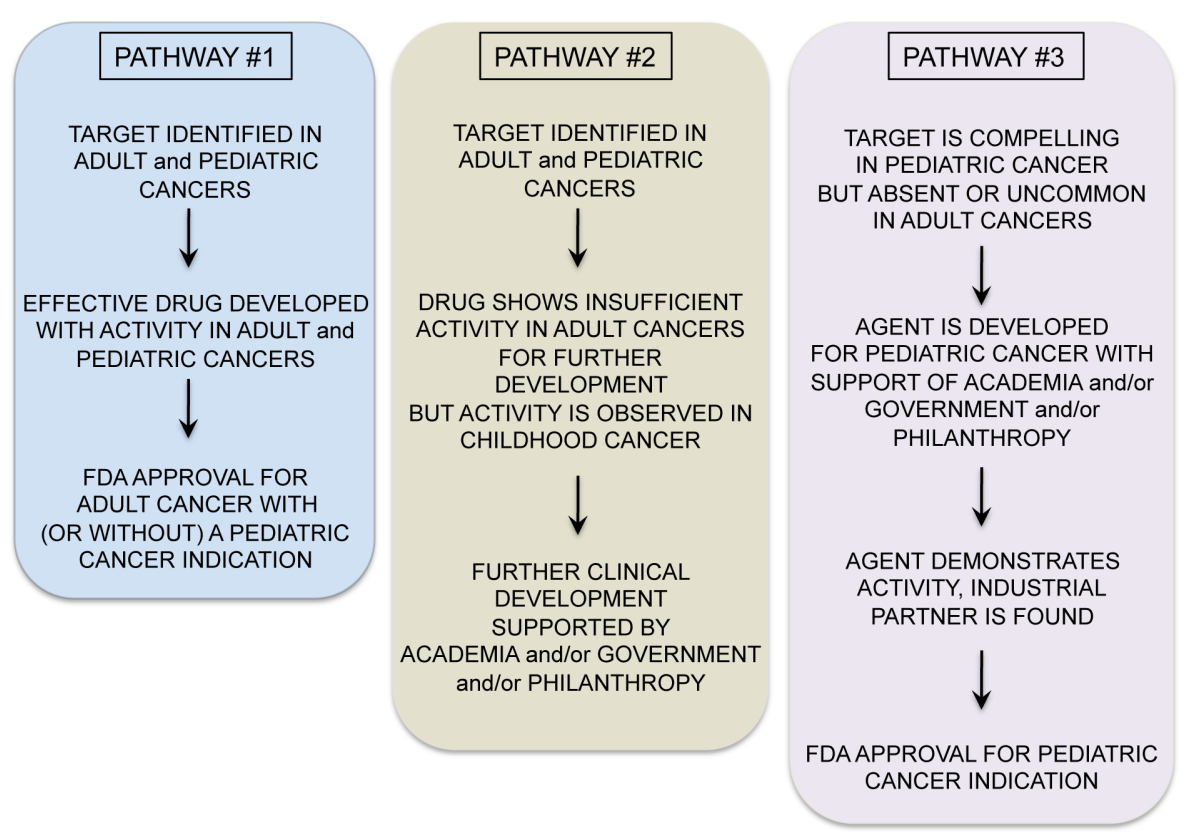

FIGURE 1 | Pathways for targeted cancer drug development in pediatric oncology.

demonstrate activity against adult cancers limits opportunities for further study in children. The academic pediatric oncology community plays a critical role in advocating for and conducting such studies. Finally, Pathway \#3 occurs (Figure 1) when targeted agents have limited or no applicability in adult cancers but are very promising for childhood cancers. Because the market size for therapies targeting pediatric tumors is generally too small to drive development by pharmaceutical and biotechnology companies, academic and governmental institutions bear the burden of developing agents with activity limited to pediatric cancer (Adamson et al., 2005). While challenging, this model can succeed. For example, a recent study demonstrated impressive activity of ch14.18 anti-GD2 moAb in a randomized Phase III trial in high-risk neuroblastoma (Yu et al., 2010). This agent was entirely developed by academia and an industrial partner was found only after the positive Phase III trial was completed.

In summary, childhood cancer care is simultaneously facing a period of great opportunity and great challenge as we work to move pediatric cancer therapies into the targeted era. The essential role of the academic pediatric oncology community in realizing this goal cannot be over- emphasized. The academic community will drive the science that identifies targets that childhood cancers share in common with adult tumors as well as in identifying unique targets for pediatric cancers. The academic community will prioritize agents for study and cooperate to undertake the most informative, yet most efficient studies of these targeted agents to minimize the numbers of patients needed to make valid conclusions. Frontiers in Pediatric Oncology seeks to provide a forum for rapid dissemination of basic, preclinical, and clinical studies as well as policy discussions aimed at hastening the pace of development of targeted therapies for childhood cancer. The explosion in biologic insights and technology that the entire biomedical research community has witnessed over the last 25 years can and must be leveraged to improve outcomes for all children with cancer and to reduce the cost of cure. It is up to those of us committed to the field of pediatric oncology to make this happen.

\section{REFERENCES}

Adamson, P. C., Weiner, S. L., Simone, J. V., and Gelband, H. (2005). Making Better Drugs for Children with Cancer. Washington, DC: National Academies Press. Aldrich, M. C., Zhang, L., Wiemels, J. L., Ma, X., Loh, M. L., Metayer, C., Selvin, S., Feusner, J., Smith, M. T., and Buffler, P. A. (2006). Cytogenetics of Hispanic and White children with acute lymphoblastic leukemia in California. Cancer Epidemiol. Biomarkers Prev. 15, 578-581.

Angiolillo, A. L., Yu, A. L., Reaman, G., Ingle, A. M., Secola, R., and Adamson, P. C. (2009). A phase II study of Campath-1H in children with relapsed or refractory acute lymphoblastic leukemia: a Children's Oncology Group report. Pediatr. Blood Cancer 53, 978-983.

Attias, D., and Weitzman, S. (2008). The efficacy of rituximab in high-grade pediatric B-cell lymphoma/ leukemia: a review of available evidence. Curr. Opin. Pediatr. 20, 17-22.

Bercovich, D., Ganmore, I., Scott,L.M., Wainreb, G., Birger, Y., Elimelech, A., Shochat, C., Cazzaniga, G., Biondi, A., Basso, G., Cario, G., Schrappe, M., Stanulla, M., Strehl, S., Haas, O.A., Mann, G., Binder, V., Borkhardt, A., Kempski, H., Trka, J., Bielorei, B., Avigad, S., Stark, B., Smith, O., Dastugue, N., Bourquin, J. P., Tal, N. B., Green, A. R., and Izraeli, S. (2008). Mutations of JAK2 in acute lymphoblastic leukaemias associated with Down's syndrome. Lancet 372, 1484-1492.

Bhatia, S. (2011). Disparities in cancer outcomes: lessons learned from children with cancer. Pediatr. Blood Cancer 56, 994-1002.

Bhatia, S., Sather, H. N., Heerema, N. A., Trigg, M. E., Gaynon, P. S., and Robison, L. L. (2002). Racial and ethnic differences in survival of children with acute lymphoblastic leukemia. Blood 100, 1957-1964.

Children's Oncology Group, Aplenc, R., Alonzo, T. A., Gerbing, R. B., Smith, F. O., Meshinchi, S., Ross, J. A., Perentesis, J., Woods, W. G., Lange, B. J., and Davies, S. M. (2006). Ethnicity and survival in childhood acute myeloid leukemia: a report from the Children's Oncology Group. Blood 108, 74-80.

Dougherty, M. J., Santi, M., Brose, M. S., Ma, C., Resnick, A. C., Sievert, A. J., Storm, P. B., and Biegel, J.A. (2010). Activating mutations in BRAF characterize a spectrum of pediatric low-grade gliomas. Neuro Oncol. $12,621-630$. 
DuBois, S. G., and Grier, H.E. (2009). Chemotherapy: the role of ifosfamide and etoposide in Ewing sarcoma. Nat. Rev. Clin. Oncol. 6, 251-253.

Fox, E., Widemann, B. C., Whitcomb, P. O., Aikin, A., Dombi, E., Lodish, M., Stratakis, C. A., Steinberg, S., Wells, S. A., and Balis, F. M. Jr. (2009). Phase I/II Trial of Vandetanib in Children and Adolescents With Hereditary Medullary Thyroid Carcinoma. Orlando, FL: American Society of Clinical Oncology, 15s.

Gaikwad, A., Rye, C. L., Devidas, M., Heerema, N. A., Carroll, A. J., Izraeli, S., Plon, S. E., Basso, G., Pession, A., and Rabin, K. R. (2009). Prevalence and clinical correlates of JAK2 mutations in down syndrome acute lymphoblastic leukaemia. Br. J. Haematol. 144, 930-932.

Gambacorti-Passerini, C., Messa, C., and Pogliani, E. M. (2011). Crizotinib in anaplastic large-cell lymphoma. N. Engl. J. Med. 364, 775-756.

Geenen, M. M., Cardous-Ubbink, M. C., Kremer, L. C., van den Bos, C., van der Pal, H. J., Heinen, R. C., Jaspers, M. W., Koning, C. C., Oldenburger, F., Langeveld, N. E., Hart, A. A., Bakker, P. J., Caron, H. N., and van Leeuwen, F.E. (2007). Medical assessment of adverse health outcomes in long-term survivors of childhood cancer. JAMA 297, 2705-2715.

Hargrave, D., Bartels, U., and Bouffet, E. (2006). Diffuse brainstem glioma in children: critical review of clinical trials. Lancet Oncol. 7, 241-248.

Harvey, R. C., Mullighan, C. G., Wang, X., Dobbin, K. K., Davidson, G. S., Bedrick, E. J., Chen, I. M., Atlas, S. R., Kang, H., Ar, K., Wilson, C. S., Wharton, W., Murphy, M., Devidas, M., Carroll, A. J., Borowitz, M. J., Bowman, W. P., Downing, J. R., Relling, M., Yang, J., Bhojwani, D., Carroll, W. L., Camitta, B., Reaman, G. H., Smith, M., Hunger, S. P., and Willman, C. L. (2010). Identification of novel cluster groups in pediatric high-risk B-precursor acute lymphoblastic leukemia with gene expression profiling: correlation with genome-wide DNA copy number alterations, clinical characteristics, and outcome. Blood 116, 4874-4884.

Hoffmann, K. M., Moser, A., Lohse, P., Winkler, A., Binder, B., Sovinz, P., Lackner, H., Schwinger, W., Benesch, M., and Urban, C. (2008). Successful treatment of progressive cutaneous mastocytosis with imatinib in a 2-year-old boy carrying a somatic KIT mutation. Blood 112, 1655-1657.

Hon,Y.Y., Fessing, M.Y.,Pui, C.H., Relling,M.V., Krynetski, E. Y., and Evans, W. E. (1999). Polymorphism of the thiopurine S-methyltransferase gene in AfricanAmericans. Hum. Mol. Genet. 8, 371-376.

Janeway, K. A., Kim, S. Y., Lodish, M., Nosé, V., Rustin, P., Gaal, J., Dahia, P. L., Liegl, B., Ball, E. R., Raygada, M., Lai, A. H., Kelly, L., Hornick, J. L., NIH Pediatric and Wild-Type GIST Clinic, O'Sullivan, M., de Krijger, R. R., Dinjens, W. N., Demetri, G. D., Antonescu, C. R., Fletcher, J. A., Helman, L., and Stratakis, C. A. (2011). Defects in succinate dehydrogenase in gastrointestinal stromal tumors lacking KIT and PDGFRA mutations. Proc. Natl. Acad. Sci. U.S.A. 108, 314-318.

Janoueix-Lerosey, I., Lequin, D., Brugieres, L., Ribeiro, A., de Pontual, L., Combaret, V., Raynal, V., Puisieux, A., Schleiermacher, G., Pierron, G., Valteau-Couanet, D., Frebourg, T., Michon, J., Lyonnet, S., Amiel, J., and Delattre, O. (2008). Somatic and germline activating mutations of the ALK kinase receptor in neuroblastoma. Nature 455, 967-970.

Ladenstein, R., Potschger, U., Le Deley, M. C., Whelan, J., Paulussen, M., Oberlin, O., van den Berg, H., Dirksen, U., Hjorth, L., Michon, J., Lewis, I., Craft, A., and
Jürgens, H. (2010). Primary disseminated multifocal Ewing sarcoma: results of the Euro-EWING 99 trial. J. Clin. Oncol. 28, 3284-3291.

Lange, B. J., Smith, F. O., Feusner, J., Barnard, D. R., Dinndorf, P., Feig, S., Heerema, N. A., Arndt, C. Arceci, R. J., Seibel, N., Weiman, M., Dusenbery, K., Shannon, K., Luna-Fineman, S., Gerbing, R. B. and Alonzo, T. A. (2008). Outcomes in CCG-2961, a children's oncology group phase 3 trial for untreated pediatric acute myeloid leukemia: a report from the Children's Oncology Group. Blood 111, 1044-1053.

Levis, M., Ravandi, F., Wang, E. S., Baer, M. R., Perl, A. Coutre, S., Erba, H., Stuart, R. K., Baccarani, M., Cripe, L. D., Tallman, M. S., Meloni, G., Godley, L. A., Langston, A. A., Amadori, S., Lewis, I. D. Nagler, A., Stone, R., Yee, K., Advani, A., Douer, D. Wiktor-Jedrzejczak, W., Juliusson, G., Litzow, M. R., Petersdorf, S., Sanz, M., Kantarjian, H. M., Sato, T., Tremmel, L., Bensen-Kennedy, D. M., Small, D., and Smith, B. D. (2011). Results from a randomized trial of salvage chemotherapy followed by lestaurtinib for patients with FLT3 mutant AML in first relapse. Blood $117,3294-3301$

Maki, R. G. (2008). Pediatric sarcomas occurring in adults. J. Surg. Oncol. 97, 360-368.

Margolin, J. F., Rabin, K. R., Steuber, C. P., and Poplack, D. G. (2011). "Acute lymphoblastic leukemia," in Principles and Practice of Pediatric Oncology, 6th Edn, eds P. A. Pizzo and D. G. Poplack (Philadelphia, PA: Lippincott Williams \& Wilkins), 518-566.

Meinhardt, A., Burkhardt, B., Zimmermann, M. Borkhardt, A., Kontny, U., Klingebiel, T., Berthold F., Janka-Schaub, G., Klein, C., Kabickova, E., Klapper, W., Attarbaschi, A., Schrappe, M., Reiter, A., and Berlin-Frankfurt-Münster group. (2010). Phase II window study on rituximab in newly diagnosed pediatric mature B-cell non-Hodgkin's lymphoma and Burkitt leukemia. J. Clin. Oncol. 28, 3115-3121.

Millot, F., Guilhot, J., Nelken, B., Leblanc, T., De Bont, E. S., Békassy, A. N., Gadner, H., Sufliarska, S., Stary, J., Gschaidmeier, H., Guilhot, F., and Suttorp, M. (2006). Imatinib mesylate is effective in children with chronic myelogenous leukemia in late chronic and advanced phase and in relapse after stem cell transplantation. Leukemia 20, 187-192.

Mosse, Y. P., Laudenslager, M., Longo, L., Cole, K. A., Wood, A., Attiyeh, E. F., Laquaglia, M. J., Sennett, R., Lynch, J.E., Perri, P., Laureys, G., Speleman, F., Kim, C. Hou, C., Hakonarson, H., Torkamani, A., Schork, N. J., Brodeur, G. M., Tonini, G. P., Rappaport, E., Devoto, M., and Maris, J. M. (2008). Identification of ALK as a major familial neuroblastoma predisposition gene. Nature 455, 930-935.

Mullighan, C. G., Zhang, J., Harvey, R. C., CollinsUnderwood, J. R., Schulman, B. A., Phillips, L. A. Tasian, S. K., Loh, M. L., Su, X., Liu, W., Devidas, M., Atlas, S. R., Chen, I. M., Clifford, R. J., Gerhard, D. S. Carroll, W. L., Reaman, G. H., Smith, M., Downing, J. R., Hunger, S. P., and Willman, C. L. (2009). JAK mutations in high-risk childhood acute lymphoblastic leukemia. Proc. Natl. Acad. Sci. U.S.A. 106, 9414-9418.

Oeffinger, K. C., Mertens, A. C., Sklar, C. A., Kawashima, T., Hudson, M. M., Meadows, A. T., Friedman, D. L., Marina, N., Hobbie, W., Kadan-Lottick, N. S. Schwartz, C. L., Leisenring, W., Robison, L. L., and Childhood Cancer Survivor Study. (2006). Chronic health conditions in adult survivors of childhood cancer. N. Engl. J. Med. 355, 1572-1582.
Pappo, A. S., and Janeway, K. A. (2009). Pediatric gastrointestinal stromal tumors. Hematol. Oncol. Clin. North Am. 23, 15-34.

Passoni, L., Longo, L., Collini, P., Coluccia, A. M., Bozzi, F., Podda, M., Gregorio, A., Gambini, C., Garaventa, A., Pistoia, V., Del Grosso, F., Tonini, G. P., Cheng, M., Gambacorti-Passerini, C., Anichini, A., FossatiBellani, F., Di Nicola, M., and Luksch, R. (2009). Mutation-independent anaplastic lymphoma kinase overexpression in poor prognosis neuroblastoma patients. Cancer Res. 69, 7338-7346.

Patel, S., Pappo, A. S., Crowley, J., Reinke, D., Eid, J., Ritland, S., Chawla, S., Staddon, A., Maki, R., Vassal, G., and Helman, L. (2009). A SARC Global Collaborative Phase II Trial of R1507, a Recombinant Human Monoclonal Antibody to the Insulin-Like Growth Factor-1 Receptor (IGF1R) in Patients With Recurrent or Refractory Sarcomas. Orlando, FL: American Society of Clinical Oncology. [Abstract \#10503].

Percy, C. L., Smith, M. A., Linet, M., Gloeckler, R., and Friedman, D. L. (1999). "Lymphomas and reticuloendothelial neoplasms", in Cancer Incidence and Survival Among Children and Adolescents: United States SEER Program 1975-1995, eds L. A. G. Ries, M. A. Smith, J. G. Gurney, M. Linet, T. Tamra, J. L. Young, and G. R. Bunin (Bethesda, MD: National Cancer Institute, SEER Program), 35-50.

Perez, E. A., Kassira, N., Cheung, M. C., Koniaris, L. G., Neville,H.L., and Sola,J.E. (2011).Rhabdomyosarcoma in children: a SEER population based study.J. Surg. Res. doi:10.1016/j.jss.2011.03.001. [Epub ahead of print].

Pieters, R. (2009). Infant acute lymphoblastic leukemia: lessons learned and future directions. Curr. Hematol. Malig. Rep. 4, 167-174.

Pollock, B. H., DeBaun, M. R., Camitta, B. M., Shuster, J. J., Ravindranath, Y., Pullen, D. J., Land, V. J., Mahoney, D. H. Jr., Lauer, S. J., and Murphy, S. B. (2000). Racial differences in the survival of childhood B-precursor acute lymphoblastic leukemia: a Pediatric Oncology Group Study. J. Clin. Oncol. 18, 813-823.

Poulikakos, P. I., and Rosen, N. (2011). Mutant BRAF melanomas-dependence and resistance. Cancer Cell 19, 11-15.

Price, V. E., Fletcher, J. A., Zielenska, M., Cole, W., Viero, S., Manson, D. E., Stuart, M., and Pappo, A. S. (2005). Imatinib mesylate: an attractive alternative in young children with large, surgically challenging dermatofibrosarcoma protuberans. Pediatr. Blood Cancer 44 , 511-515.

Quintas-Cardama, A., Kantarjian, H., Cortes, J., and Verstovsek, S. (2011). Janus kinase inhibitors for the treatment of myeloproliferative neoplasias and beyond. Nat. Rev. Drug Discov. 10, 127-140.

Raney, R. B., Anderson, J. R., Barr, F. G., Donaldson, S. S., Pappo, A. S., Qualman, S. J., Wiener, E. S., Maurer, H. M., and Crist, W. M. (2001). Rhabdomyosarcoma and undifferentiated sarcoma in the first two decades of life: a selective review of intergroup rhabdomyosarcoma study group experience and rationale for Intergroup Rhabdomyosarcoma Study V. J. Pediatr. Hematol. Oncol. 23, 215-220.

Reiter, A., Meinhardt, A., Burkhardt, B., Zimmermann, M., Borkhardt, A., Kontny, U., Mann, G., and Schrappe, M. (2009). Phase II Window Study on Rituximab in Newly Diagnosed Pediatric Mature B-Cell Non-Hodkin Lymphoma (NHL). Orlando, FL: American Society of Clinical Oncology, 15s. [abstr 10000].

Scheurer, M. E., Bondy, M. L., and Gurney, J. G. (2011). "Epidemiology of childhood cancer," in Principles 
and Practice of Pediatric Oncology, 6th Edn, eds P. A. Pizzo and D. G. Poplack (Philadelphia, PA: Lippincott Williams \& Wilkins, A Wolters Kluwer Business), 2-16.

Schindler, G., Capper, D., Meyer, J., Janzarik, W., Omran, H., Herold-Mende, C., Schmieder, K., Wesseling, P., Mawrin, C., Hasselblatt, M., Louis, D. N., Korshunov, A., Pfister, S., Hartmann, C., Paulus, W., Reifenberger, G., and von Deimling, A. (2011). Analysis of BRAF V600E mutation in 1,320 nervous system tumors reveals high mutation frequencies in pleomorphic xanthoastrocytoma, ganglioglioma and extra-cerebellar pilocytic astrocytoma. Acta Neuropathol. 121, 397-405.

Schultz, K. R., Bowman, W. P., Aledo, A., Slayton, W. B., Sather, H., Devidas, M., Wang, C., Davies, S. M., Gaynon, P. S., Trigg, M., Rutledge, R., Burden,
L., Jorstad, D., Carroll, A., Heerema, N. A., Winick, N., Borowitz, M. J., Hunger, S. P., Carroll, W. L., and Camitta, B. (2009). Improved early event-free survival with imatinib in Philadelphia chromosome-positive acute lymphoblastic leukemia: a Children's Oncology Group Study. J. Clin. Oncol. 27, 5175-5181.

Tricoli, J. V., Seibel, N. L., Blair, D. G., Albritton, K., and Hayes-Lattin, B. (2011). Unique characteristics of adolescent and young adult acute lymphoblastic leukemia, breast cancer, and colon cancer. J. Natl. Cancer Inst. 103, 628-635.

Yu, A. L., Gilman, A. L., Ozkaynak, M. F., London, W. B., Kreissman, S. G., Chen, H. X., Smith, M., Anderson, B., Villablanca, J. G., Matthay, K. K., Shimada, H., Grupp, S. A., Seeger, R., Reynolds, C. P., Buxton, A., Reisfeld, R. A., Gillies, S. D., Cohn, S. L., Maris, J. M., Sondel, P. M., and Children's Oncology Group. (2010).
Anti-GD2 antibody with GM-CSF, interleukin-2, and isotretinoin for neuroblastoma. N. Engl. J. Med. 363 , 1324-1334.

Received: 09 June 2011; accepted: 05 July 2011; published online: 20 July 2011.

Citation: Mackall CL (2011) In search of targeted therapies for childhood cancer. Front. Oncol. 1:18. doi: 10.3389/ fonc.2011.00018

This article was submitted to Frontiers in Pediatric Oncology, a specialty of Frontiers in Oncology.

Copyright $\odot 2011$ Mackall. This is an open-access article subject to a non-exclusive license between the authors and Frontiers Media SA, which permits use, distribution and reproduction in other forums, provided the original authors and source are credited and other Frontiers conditions are complied with. 